\title{
A Comparative Analysis of Owner-Contractor Agreements in the Turkish and US Construction Industry
}

Pinar Irlayici Cakmak and Elcin Tas

Department of Architecture, Istanbul Technical University, Istanbul 34743, Turkey

\begin{abstract}
Successful and cost-effective construction relies upon appropriate communication of the participants of the construction project. Hence, it is important to define the rights and responsibilities of the parties, and relationships among them. In this context, well-designed and complete agreement is essential and necessary for the successfully completion of a construction project within the desired time, quality and budget. In this paper, it is aimed to analyze and compare the owner-contractor agreements in the Turkish and the US construction industry. First, the importance of construction contracts and contractual elements of an agreement is determined, and then, the standard owner-contractor agreement which is used in the Turkish construction industry is analyzed and compared with the US standard owner-contractor agreement. Finally, the differences between these agreements are put forward, the lack and deficiencies of Turkish standard agreement form are determined, and appropriate suggestions are improved.
\end{abstract}

Key words: AIA (American Institute of Architects), construction contracts, KIK (Kamu Ihale Kurumu), owner-contractor agreement, standard forms.

\section{Introduction}

The usual construction contract consists of a number of different documents. In order for the work to be completely defined, the contract must be accompanied by a number of other documents that (for the sake of convenience and propriety) are prepared separately from the body of the contract [1]. This collection of documents is known as contract documents. Contract documents play an important role in the development of a project and provide the bridge between the owner's conceptual image of a project and the actual construction of the physical facility [2]. All the contract documents are important for successfully completion of a construction project, but the agreement is a vital one as it defines the relationships and obligations between owner and contractor and constitutes basic principles and

Corresponding author: Pinar Irlayici Cakmak, Ph.D. candidate, research fields: construction contracts, contract documents and contract administration. E-mail: irlayici@itu.edu.tr. procedures of the contract.

This paper aims to analyze and compare the owner-contractor agreements in the Turkish and the US construction industry. In order to reach this aim, first, the construction contracts are clarified, and then, the agreement and its contractual elements are explained. Next, US AIA (American Institute of Architects) standard contract forms and Turkish KIK (Kamu Ihale Kurumu) standard forms are represented. Of these documents, the owner-contractor agreement forms are selected for the comparative analysis. In this context, first, AIA Document A101-2007 Standard Form of Agreement between Owner and Contractor is compared with the KIK Standard Contract for Construction Works. Finally, the main differences between these agreements are put forward, the lack and deficiencies of Turkish standard agreement forms are determined, and appropriate suggestions are improved. 


\section{Construction Contracts}

A contract is a legal agreement between two or more parties that agree to be bound in a relationship. These parties are bound to each other for a certain period of time by a unique and exclusive relationship they have created for their mutual benefit [3]. Although there are many types of construction contracts, they can be divided into two main groups, based on the number of contracts (such as single-prime and multiple-prime contracts) and method of payment to the contractor (such as lump sum, unit price and cost-plus,).

In terms of the number of contracts, usually an owner initiates a single-prime construction contract or multiple-prime contracts. A single-prime contract is a common form of construction contracting. In single-prime contracts, the owner and contractor enter into a contract formalizing their relationship and their obligations. Besides, in a multiple-prime construction contract, the work is divided among several contractors, and the owner enters into a separate contract with each contractor.

Construction contracts also differ based on the method of payment to the contractor. First of all is the lump sum contract, which is the most popular fixed price contract, where the total price of the project is estimated at the bidding stages [2]. In this type of contract, there is an agreed amount for a described extent of work, based upon complete or partially complete construction documents. Lump-sum contracts are preferred when the scope of the project is well defined with predictable costs and low implementation risks [3]. The second one is unit price contracts, which are based on the unit price for each parties of the construction. In this type of contract, payment is made at a stipulated rate multiplied by the quantity completed. Unit prices are used in cases where the exact extent or quantity of work cannot be calculated accurately or determined in advance of actually performing the work. The decision whether to choose working with unit price contract depends on the amount of risk which is inversely proportional to the indefiniteness of the available information [3]. Another contract is cost-plus-fee contracts, which are derived either by adding a pre-established percentage mark-up to each item in the schedule, or by applying a fixed pre-determined fee for overhead and profit [1]. In a cost plus fixed fee contract, the owner and contractor agree on the fee that covers the profit and expenses of the contractor when drafting the contract [2]. Various types of cost-plus-fee contracts are cost plus percentage, cost-plus-fixed fee, cost-plus incentive fee and maximum cost-plus-fee contracts. The last one is the guaranteed maximum price contact, which is agreed upon maximum contract sum not to be exceeded. In this type of contract, the contractor guarantees that the project will be constructed in full accordance with the drawings and specifications and the cost to the owner will not exceed some total upset price [4]. Furthermore, the owner has a possibility of reducing costs and the contractor has a chance to increase his profit.

Depending on the project delivery, the number of contracts, and the basis of payment, a specific form of agreement will be required which will state the relationships and obligations of the signing parties for the variations involved.

\subsection{The Agreement}

Although often referred to as the contract, the construction agreement is only one of the various documents that make up the contract documents which specifically designed to formalize the construction contract and legally obligates the signing parties. The key component for the contract for construction is the agreement between owner and contractor. The agreement defines the relationships and obligations between owner and contractor and acts as a single instrument that serves the purpose of presenting a condensation of the contract elements, stating the work to be done and the price to be paid for it, and provides suitable spaces for the signatures of 
the parties [4].

According to the Construction Specification Institute [5], the owner-contractor agreement typically includes articles relating to the following: (1) contract documents: a detailed list of all written and graphic documents that are part of the contract; (2) contract time: start and completion dates or allotted calendar days for the project; (3) contract price: the basis on which applications for payment will be made, and includes the listing of any unit prices, allowances and accepted alternates; (4) payment procedures: identifies when the contractor will submit applications for payment and when payment by the owner to the contractor will be made.

In order for the work to be completely defined, the agreement incorporates all of the other documents that make up the contract documents: contracting forms; project forms; conditions of the contract (general and supplementary conditions); specifications; contract drawings; and revisions (addenda), clarifications and modifications [5]. Of these documents, the agreement and the conditions of the contract have been developed by professional associations into standard forms.

\subsection{Standard Agreement Forms}

Several professional associations and government authorities have developed various standard agreement forms. This standardization of agreement forms has several advantages such as saving preparation time, proposing a complete and accurate document and eliminating disagreement areas between the contracting parties. Through repeated use, forms with standardized clauses have become well understood by owners, architects/engineers, suppliers, and contractors and are less subject to misinterpretation [5]. In addition, they have withstood the test of time and experience and have become familiar to architects/engineers and contractors who clearly understand their meanings and implications [4].

Standardized versions of several agreement forms have been developed by various professional, business and public organizations. Some of these professional associations which develop standard agreement forms in the United States are the AIA (American Institute of Architects), the AGC (Associated General Contractors) of America, the EJCDC (Engineers Joint Contract Documents Committee), and the DBIA (Design-Build Institute of America). Several different standard agreement forms have been published by these associations for the various project delivery methods and basis of payments. As AIA documents are referred to the most widely used standard forms [3], AIA standard agreement forms are preferred to make the comparative analysis.

\subsection{AIA Standard Agreement Forms}

The AIA was founded in the US in 1857, has been the leading professional membership association that represents member architects and related professionals. The main approach of this association is to promote the scientific and practical perfection of its members and to elevate the standing of the profession [6]. In this regard, AIA publishes standard contract forms for the design and construction industry in order to manage the relationships involved in construction projects.

AIA organizes its standard contract forms into two main groups and the classification of documents can be seen in Table 1. The first group is AIA series, which is based on the use of the document and the parties of the agreement. The second one is AIA families, which is based on the types of projects or particular project delivery methods.

As this paper is concentrated on the owner-contractor agreements, it is important to explain AIA's A Series. A Series include standard forms related to owner-contractor agreements. In A Series, there are 27 different standard forms. Of these standard forms, there are six types of owner-contractor agreements for different project delivery systems, payment methods and project types. 
Table 1 Classification of AIA contract forms.

\begin{tabular}{ll}
\hline AIA series & AIA families \\
\hline A Series: Owner/contractor agreements & Conventional (A201) family \\
B Series: Owner/architect agreements & CMA (construction manager as adviser) family \\
C Series: Other agreements & CMC (construction manager as constructor) family \\
D Series: Miscellaneous documents & Design-build family \\
E Series: Exhibits & IPD (integrated project delivery) family \\
G Series: Contract administration and project management forms & Interiors family \\
& International family \\
& Small projects family \\
\hline
\end{tabular}

Moreover, there are eight more owner related agreement forms for different participants such as construction manager, design-builder, vendor and subcontractor. A Series also includes general conditions of the contract for construction, guide for supplementary conditions, instruction to bidders and bonds.

As this paper deals with the owner-contractor agreements, AIA Document A101-2007 standard form of Agreement between owner and contractor is selected for the comparative analysis.

A101 is intended for use on construction projects where the basis of payment is a stipulated sum (fixed price). It is suitable for any arrangement between the owner and contractor where the cost has been set in advance, either by bidding or by negotiation [7]. A101 has 10 main articles which are: (1) the contract documents; (2) the work of this contract; (3) date of commencement and substantial completion; (4) contract sum; (5) payments; (6) dispute resolution; (7) termination or suspension; (8) miscellaneous provisions; (9) enumeration of contract documents; (10) insurance and bonds.

\subsection{KIK Standard Agreement Forms}

In Turkey, the only association which publishes standard contract forms is a governmental authority, Public Procurement Authority (KIK). The standard contract forms are government contracts which are developed based on the Turkish Public Procurement Law No. 4734 [8]. Although the construction project participants are free to use any standard contract forms in their private construction works, KIK standard contract forms are compulsory for the public construction works in Turkey.

KIK has two different contract document groups related to construction projects. The first group is for construction works procurements, and the second one is for consultancy services procurements. The classification of KIK contract documents is given in Table 2.

Unlike AIA, KIK has one and only standard form for owner-contractor agreements. The standard form of agreement between owner and contractor is named as SCCW (standard contract for construction works). SCCW has 35 main articles consist of provisions about the parties, contract type and price, bonds, payments, etc. [9]. This owner-contractor agreement is used with each project delivery system and payment methods.

\section{Comparative Analysis of Owner-Contractor Agreements}

Following table compares the standard form of agreement of AIA/A101 and KIK/SCCW in terms of the basic articles they are composed of. To compare the two agreement documents: Firstly, AIA/A101 form's basic articles are expanded; Then, it is searched that whether the KIK/SCCW agreement has corresponding provisions or not. As shown in Table 3, the corresponding provisions are given in the related rows. Besides, provisions that are not found are marked with an asterisk (*).

In Table 3, A101's 10 main articles with their own sub-articles are listed. Likewise, SCCW's corresponding provisions are given in the related next column. 
Table 2 Classification of KIK contract forms.

\begin{tabular}{|c|c|}
\hline Construction works procurements & Consultancy services procurements \\
\hline $\begin{array}{l}\text { Standard contract for construction works } \\
\end{array}$ & \\
\hline General specifications for construction works & Standard contract for consultancy services \\
\hline Standard administrative specification for the works procurements & Standard administrative specification for consultancy services \\
\hline $\begin{array}{l}\text { Standard prequalification specification for the works procurements } \\
\text { through the restricted tender procedure }\end{array}$ & Standard prequalification specification for consultancy services \\
\hline
\end{tabular}

It is seen that SCCW does not correspond AIA's many articles. Even, when the contents of the articles are deeply analyzed, it is seen that SCCW has several lacks when compared to A101.

These lacks are specifically shown in the provisions about the third parties, contract documents, contract sum, payments and dispute resolution.

One of the most important lacks in SCCW is that, there is no provision about the identification of the third parties. However, A101 identify the architect as a third party and has given the contract administration duties and responsibilities to the architect as the owner's representative. Although the architect is not one of the signing parties, A101 gives the necessary information about the architect in its cover page. SCCW does not deal with any representatives and does not give any clue about the contract administration. On the other hand, the owner and contractor can also have their own representatives and their information is given in the miscellaneous provisions.

In A101, a list of contract documents is given in Article 1 and the details of each contract document are explained in Article 9. According to A101, contract documents consist of the agreement, conditions of the contract (general, supplementary and other conditions), drawings, specifications, addenda (issued prior to execution of the agreement), other documents listed in the agreement and modifications (issued after execution of the agreement). A101 gives priority to no particular contract document; each contract document has equal importance. SCCW also has provisions about contract documents but unlike A101, it has a statement concerning the relative priority of the contract documents among them. SCCW gives a list of contract documents by giving no explanations about them. According to their priorities, contract documents are: general conditions, administrative conditions, draft agreement, drawings, location lists, special technical specifications, general technical specifications, clarifications (if any) and other annexes.

Another difference is about the provisions related to the contract sum. A101 in its Article 4, allows the owner to decrease the cost by changing some construction items or identifying alternates. New unit prices can also be identified and adjustments can be made in the contract sum. However, SCCW does not allow any changes and there are no provisions about adjustments in the contract sum.

The progress payment procedure is also different in both agreements. As it is shown in Fig. 1, in A101, the contractor applies to the architect for the progress payments. After the architect's evaluation, the owner makes the payment to the contractor. The time of the progress payments is also indicated in the related space in Article 5. On the other hand, in SCCW, the contractor directly applies to the owner for the progress payments. After the evaluation within 30 days, the payment is made in 15 days.
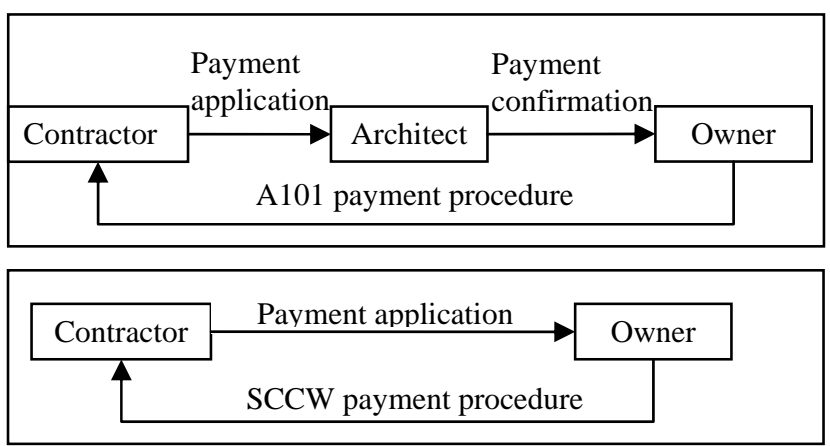

Fig. 1 Progress payment procedures. 
Table 3 Comparison of AIA/A101 and KIK/SCCW agreements.

\begin{tabular}{|c|c|c|c|}
\hline AIA/A101 & KIK/SCCW & AIA/A101 & KIK/SCCW \\
\hline Cover page & $*$ & A.5 Payments & \multirow{3}{*}{ A.11 Place and terms of payment } \\
\hline 1. Date & A.34 Enforcement & 5.1 Progress payments & \\
\hline 2. Owner & \multirow{2}{*}{$\begin{array}{l}\text { A.1 Parties to the contract } \\
\text { A.2 Information about the } \\
\text { parties }\end{array}$} & 5.2 Final payment & \\
\hline 3. Contractor & & A.6 Dispute resolution & A.31 Settlement of disputes \\
\hline 3. Project & $\begin{array}{l}\text { A.3 Name, location, nature, } \\
\text { type and amount of work }\end{array}$ & 6.1 Initial decision maker & $*$ \\
\hline 4. Architect & $*$ & 6.2 Binding dispute resolution & $*$ \\
\hline A.1 The contract documents & A.8 Annexes to the contract & A.7 Termination or suspension & \multirow{2}{*}{$\begin{array}{l}\text { A.26 Terms of termination of } \\
\text { contract }\end{array}$} \\
\hline A.2 The work of this contract & * & 7.1 Termination & \\
\hline $\begin{array}{l}\text { A.3 Date of commencement } \\
\text { and substantial completion }\end{array}$ & \multirow{4}{*}{$\begin{array}{l}\text { A.9 Date of commencement } \\
\text { and completion of work and } \\
\text { penalties applicable for } \\
\text { delays }\end{array}$} & 7.2 Suspension & $\begin{array}{l}\text { A.27 Increased works, decreased } \\
\text { works and dissolution works } \\
\text { under contract }\end{array}$ \\
\hline $\begin{array}{l}\text { 3.1 The date of } \\
\text { commencement of the work }\end{array}$ & & A.8 Miscellaneous provisions & A.32 Miscellaneous provisions \\
\hline 3.2 The contract time & & 8.1 Reference & \multirow{6}{*}{ * } \\
\hline 3.3 Substantial completion & & 8.2 Interest rate & \\
\hline A.4 Contract sum & \multirow[b]{2}{*}{ A.6 Contract type and price } & 8.3 The owner's representative & \\
\hline 4.1 The contract sum & & $\begin{array}{l}\text { 8.4 The contractor's } \\
\text { representative }\end{array}$ & \\
\hline 4.2 Alternates & \multirow{3}{*}{ * } & 8.5 Change of representatives & \\
\hline 4.3 Unit prices & & 8.6 Other provisions & \\
\hline 4.4 Allowances & & $\begin{array}{l}\text { A.9 Enumeration of contract } \\
\text { documents }\end{array}$ & A.8 Annexes to the contract \\
\hline & & A.10 Insurance and bonds & $\begin{array}{l}\text { A.17 Protecting and insuring the } \\
\text { work and worksite }\end{array}$ \\
\hline
\end{tabular}

Another important lack of SCCW is about dispute resolution. In A101's Article 6, the owner and contractor may identify an initial decision maker to render initial decisions on claims arising between them. If the parties do not identify an initial decision maker, then the architect will provide initial decisions. Besides, the parties can select from three choices of binding dispute resolution such as arbitration, litigation or another method that the parties identify [7]. However, SCCW does not present and allow any dispute resolution method. SCCW indicates that the disputes that may arise between the parties during the execution of the contract shall be settled by the Turkish courts.

\section{Conclusions}

This paper analyzed the Turkish standard owner-contractor agreement (KIK/SCCW) in by comparing it with the US agreement (AIA/A101).
When compared with A101, it is found that some important provisions are missing in SCCW. These missing provisions are shown in the important contractual elements such as identification of the third parties, contract documents, contract sum, payments and dispute resolution. Due to the lack of these elements, the agreement is not sufficient, comprehensive and useful both in scope and content.

When SCCW is analyzed, it can be seen that, there is a need of a new series of owner-contractor agreements which provides a wide range of forms to meet the various and diverse needs different project delivery systems and payment methods. One type agreement cannot be appropriate for all the project types and payment methods. Besides, the agreement has to be accompanied by other contract documents and required explanations have to be given within the agreement.

Although the owner and contractor are the only 
signing parties of the agreement, a third party is required for the contract administration. SCCW has to add necessary provisions about contract administration and assign a representative to fulfill these administration duties and responsibilities.

Because of the nature of the construction itself, there can be a need of making modifications or additions to the statements in the agreement. However, it is impossible to make changes in SCCW, especially, in the contract sum, construction items and unit prices. SCCW needs to be revised in order to allow changes and adjustments.

Another important problem in SCCW is the lack of a mechanism about dispute resolution procedure. If any dispute arises between the parties, SCCW should propose an alternative dispute resolution mechanism such as mediation or arbitration as they avoid the increasing caseload of traditional courts.

To conclude, the agreement plays vital roles in order to successfully complete of the construction projects within the desired goals. Due to the lack of some important contractual elements, problems are inevitable between the parties. Therefore, new and comprehensive series of owner-contractor agreement with revised provisions is required for the successfully completion of the construction projects in the Turkish construction industry.

\section{References}

[1] W.S. Poage, The Building Professional's Guide to Contract Documents, 3rd ed., R.S. Means Co., Kingston, MA, 2000.

[2] J. Hinze, Construction Contracts, McGraw-Hill, New York, 2001.

[3] K. Collier, Construction Contracts, Upper Saddle River, Merrill/Prentice Hall., New Jersey, 2001.

[4] R.H. Clough, G.A. Sears, S.K. Sears, Construction Contracting: A Practical Guide to Company Management, 7th ed., Wiley, Hoboken, 2005.

[5] The CSI Project Delivery Practice Guide, The Construction Specification Institution, Wiley, Hoboken, 2011.

[6] The American Institute of Architects, http://www.aia.org (accessed Dec. 20, 2013).

[7] AIA Document A101-2007 Standard Form of Agreement between Owner and Contractor, The American Institute of Architects, 2007.

[8] Kamu Ihale Kurumu, http://www.ihale.gov.tr (accessed Nov. 15, 2013).

[9] Standard Contract for Construction Works, Kamu Ihale Kurumu, 2011. (in Turkish) 